\title{
Influence of the Rubber Seed Type and Altitude on Characteristic of Seed, Oil and Biodiesel
}

\author{
Salni $^{\mathrm{a}}$, Poedji Loekitowati Hariani ${ }^{\mathrm{b}^{*}}$ and Hanifa Marisa ${ }^{\mathrm{a}}$ \\ ${ }^{a}$ Department of Biology, Faculty of Mathematics and Natural Science, Sriwijaya University, Indonesia \\ ${ }^{b}$ Department of Chemistry, Faculty of Mathematics and Natural Science, Sriwijaya University, Indonesia
}

\begin{abstract}
This research studies the influence of the type of rubber seed that is superior and local, altitude plant in South Sumatra province to the characteristic of seed, oil and biodiesel (methyl ester). Rubber plants planted from local rubber seed by seeds seedlings and superior rubber seed by selected clones. In the study, rubber plants planted at a different altitude, namely in Banyuasin district (18 m above sea level), Prabumulih District (176 m above sea level) and Lahat District (627 m above sea level). The results showed that the weight of the flour, the water content and ash content in the local rubber seeds larger than the superior rubber seed for all altitude, but oil content a large in the superior rubber seeds. The major of fatty acids in the rubber seed oil in all types and altitude are a linoleic acid with a different percentage except local rubber seed oil from Lahat district with the large percentage of octadecanoic acid. Free fatty acids in the oil from the superior seeds rubber of 13.897-15.494 \% large than local rubber seed oil was found 9.786-10.399 \% for all altitude. By esterification process using sulfuric acid catalyst, Free Fatty Acid (FFA) can be reduced to $\leq 2 \%$. The methyl ester made from the transesterification process of rubber seed oil after esterification using methanol and sodium hydroxide as catalyst. Analysis of methyl esters includes cetane index, flash point, kinematic viscosity, carbon residue, density, moisture content, water and sediment content and distillation compared with SNI 7182 and ASTM 6751-02. The result indicated that the quality of methyl ester from superior rubber seed oil in the Banyuasin and Prabumulih district better than another methyl ester. The types of rubber seed altitude affect the characteristics of the seed, oil and methyl ester but the altitude are not significantly different.
\end{abstract}

Keywords: rubber seed, type, altitude, oil, biodiesel

Article History: Received March 21 ${ }^{\text {st }} 2017$; Received in revised form May $5^{\text {th }} 2017$; Accepted June $2^{\text {nd }} 2017$; Available online How to Cite This Article: Salni, S, Hariani, P.L. and Marisa, H. (2017) Influence the Rubber Seed Type and Altitude on Characteristic of Seed, Oil and Biodiesel. International Journal of Renewable Energy Develeopment, 6(2), 157-163.

https://doi.org/10.14710/ijred.6.2.157-163

\section{Introduction}

Biodiesel (methyl ester) is an alternative energy that can replace the presence of diesel fuel. Biodiesel is commonly made from vegetable oil. Vegetable oil and biodiesel belong to the large class of organic compounds are ester fatty acids. However, vegetable oils are triesters of fatty acids with glycerol, or triglycerides, while biodiesel or fatty acid methyl ester (FAME) is monoesters of fatty acids with methanol or ethanol by transesterification process (Ramadhas, et al. 2005; Hossain \& Mazen, 2010).

The use of biodiesel from edible oil has a negative impact because it competes with its use as food consumption (Chuah, et al. 2015). Therefore, biodiesel from non-edible oil is developed. One source of edible oil widely available in Indonesia is rubber seed. Rubber seed oil dries classified as type oil (drying oil) (Ketaren, 1986). The yield oil in rubber seed in the average 35-45 $\%$ from different countries reported by Kittigowittana et al (2013).

Research in biodiesel from rubber seed oil has been developed, such as the type of catalyst, alcohol mass ratio, temperature, the concentration of catalyst (Widayat \& Suherman, 2012; Abdulkadir, et al. 2014, Zamberi \& Ani, 2016). The chemical characteristic of oil dependent on geographical origin (Kittigowittana, et al. 2013). In addition, the quality of the oil is affected by altitude and pedology. Rouas et al. (2016) reported

\footnotetext{
* Corresponding author: pujilukitowati@yahoo.com
} 
Citation: Salni, S, Hariani, P.L. and Marisa, H. (2017) Influence the Rubber Seed Type and Altitude on Characteristic of Seed, Oil and Biodiesel.. Int. Journal of Renewable Energy Development, 6(2), 157-163, https://doi.org/10.14710/ijred.6.2.157-163

$\mathrm{P}$ a g e 158

that altitude affects the characteristic of virgin olive oil $(<300,300-600,>600 \mathrm{~m})$. The other research reported that percentage of oil significan negative relation with altitude (Dizajeyekan, et al. 2016).

Indonesia is the second largest rubber producer in the world. One of the provinces that have large farms is South Sumatra. In this area, rubber plants planted in all region altitude. Soil type in South Sumatera with acid $\mathrm{pH}$ suitable for rubber plant growth.

There are two types of rubber seed are superior and non-superior rubber seed (local rubber seeds). The farmers in Indonesia now use scraped seeds or seeds seedlings result of previous natural rubber plant. According to the Indonesian National Standard (SNI), superior rubber seeds are derived from selected vegetatively propagated clones such as grafting, cuttings, and tissue culture. The advantages of superior rubber seed include latex production of high quality and good properties of latex, ripe tapping robust growth under 4 years old and a high biomass potential.

The fatty acid methyl ester (FAME) from rubber seed oil can be produced by two step reactions. The first step is esterification and the second step is transesterification. The esterification reaction is required to reduce the content of free fatty acids (Khazaai, et al. 2017; Bello \& Otu, 2015). The rubber seed oil has a high free fatty acid (FFA) (Ahmad, et al. 2014; Ramadhas, et al. 2005). The free fatty acids in the oil can react with a base catalyst which produces soap which complicate the process of separation of esters and glycerol (Marchetti \& Errazu, 2008; Khazaai, et al. 2017). Ramadhas et al (2005) reported that free fatty acids are good for transesterification less than $2 \%$ or below $4 \mathrm{mg} \mathrm{KOH/g}$ oil.

This study investigates the characteristic of seed, oil content and methyl ester from a different type of rubber and altitude. The oil is extracted by $\mathrm{n}$ hexane as an extraction solvent. Transesterification process of rubber seed oil after esterification using methanol and sodium hydroxide as catalyst The properties of methyl ester were analyzed according to the SNI and ASTM standard.

\section{Materials and Methods}

\subsection{Rubber seeds}

The local and superior rubber seeds collected from a plantation in Banyuasin District (18 $\mathrm{m}$ above sea level), Prabumulih District (176 $\mathrm{m}$ above sea level) and Lahat District (627 m above sea level) in South Sumatera province. The longitude and latitude of South Sumatera province at $5^{0} 10^{\prime}-1^{0} 20^{\prime} \mathrm{S}$ and $101^{\circ} 40^{\prime}$ $-106^{0} 30^{\prime} \mathrm{N}$.

The superior rubber seeds namely PB-260. The rubber seed from rubber trees of the same age was given the following code: local rubber seed from Banyuasin district (BL), superior rubber seed from Banyuasin district (BS), local rubber seed from
Prabumulih district (PL), superior rubber seed from Prabumulih district (PS), local rubber seed from Lahat district (LL) and superior rubber seed from Lahat district (LS).

\subsection{Chemicals}

The chemicals used in this study include methanol, sulfuric acid, sodium hydroxide and nhexane from Merck.

\subsection{Analysis of rubber seed}

The shell and kernels of rubber seeds separated by breaking. The kernels were dried under the sun for five days before crushed using a blender. The sample is dried in the oven about $\pm 5 \mathrm{~h}$ at $105^{\circ} \mathrm{C}$. The powder of rubber seed is weighed and stored in a desicator. The rubber seeds analysis includes the weight of flour, moisture content, ash content, and oil content using recommended methods of the AOAC.

\subsection{Oil extraction}

Rubber seed powder of $100 \mathrm{~g}$ wrapped in paper filter is placed inside Soxhlet to extract. A total of 250 $\mathrm{mL} \mathrm{n}$-hexane is poured into Soxhlet. Extraction is done for 6 hours per cycle at $60^{\circ} \mathrm{C}$. The extraction process is done three times. After extraction, the oil separated from the solvent by evaporation with a rotary evaporator at $60^{\circ} \mathrm{C}$.

The rubber seed oil purification is done by deposition (settling), separation gumi (degumming) and bleaching. A total of $100 \mathrm{~mL}$ of rubber seed oil was mixed with $0.2 \% \mathrm{w} \mathrm{H}_{3} \mathrm{PO}_{4}$ and stired for 15 minutes at a speed of $120 \mathrm{rpm}$ and temperature of $50^{\circ} \mathrm{C}$. After 30 minutes, the oil is separated from the sediment. The oil was added $0.1 \mathrm{~g}$ of activated carbon and stirred for 15 minutes then allowed to stand for 2 hours. Hereafter, the oil is filtered to separate the activated carbon. The oil was added some anhydrous $\mathrm{Na}_{2} \mathrm{SO}_{4}$ to adsorp the water content. Afterward, the oil has ready for analysis. Analysis of rubber seed oil includes Free fatty acid (ASTM D664), viscosity (ASTM D4455), and fatty acid using GC-MS QP2010S Shimadzu.

\subsection{Transesterification Process}

Esterification is required before transesterification. The oil was esterified using sulfuric acid as a catalyst to reduce FFA to less than $2 \%$. Methyl ester was prepared with mixture of $10 \mathrm{~mL}$ sulfuric acid $5 \%(\mathrm{w} / \mathrm{v})$ and $300 \mathrm{~mL}$ methanol were added $50 \mathrm{~mL}$ oil (ratio of methanol and oil = 6:1) (Ramadhas, et al. 2005; Ahmad et al, 2014). The mixture was heated at $60^{\circ} \mathrm{C}$ and stirred with at $120 \mathrm{rpm}$ for 2 hours. Oil with reduced fatty acid content is separated from remaining methanol. The product is separated by rotary evaporator in a $70^{\circ} \mathrm{C}$ water bath.

Transesterification is conducted using $\mathrm{NaOH}$ as catalyst. The mixture of $0.5 \%(\mathrm{~b} / \mathrm{v}) \mathrm{NaOH} 50 \mathrm{~mL}$ and 
$450 \mathrm{~mL}$ of methanol (ratio of methanol and oil 9: 1) was added to $50 \mathrm{~mL}$ of oil. The mixture was heated for 2 hours at a temperature of $60^{\circ} \mathrm{C}$. The product has two layers. The top layer is the methyl esters while the bottom is glycerol. The two layers are separated by separating funnel. The methyl ester was neutralized with $0.05 \mathrm{M} \mathrm{HCl}$, washed with distilled water and dried with anhydrous $\mathrm{Na}_{2} \mathrm{SO}_{4}$. The remaining methanol was evaporated with a rotary evaporator.

The methyl ester analysis includes cetane number (ASTM D-976), flash point (ASTM D-56), viscosity (ASTM D-445), carbon residue (ASTM D-189), specific gravity (ASTM D-1298), Moisture content (ASTM D95), sediment (ASTM D-473) and distillation (ASTM D38).

\section{Result and Discussion}

\subsection{Characteristic of Rubber Seed}

Rubber trees were planted generatively and vegetatively. The rubber seed planted generatively is called local rubber seed while vegetatively planted rubber seed is called superior rubber seeds. The use of superior rubber seeds to get more latex. In Indonesia, local rubber seed is more common because of cheap and practical.
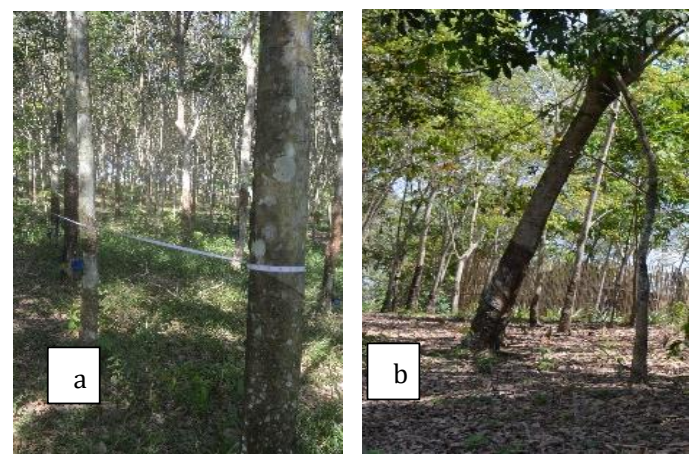

Fig. 1 The growth of rubber tree from (a) superior rubber seed and (b) local rubber seed

Figure 1 shows the growth of rubber plants from superior rubber seed and local rubber seed. The trees from local rubber seed have a cylindrical rod, that is getting smaller towards the top and not the former linkage grafting found near the soil surface. In contrast, trees are derived from superior rubber seed have rod diameter up towards the top. There is a real former grafting linkage near the soil surface. The genetic properties affect plants growth (Sham, et al. 2016).

Table 1 shows the characteristic of superior and local rubber seed. At the same weight, the superior rubber seed flour has less weight than local rubber seeds. The advantage of superior rubber seed is in the production of latex. The latex is the result from secondary metabolism while seed flour is from primary metabolism primer.
Table 1

Characteristics of Rubber Seeds

\begin{tabular}{lllllll}
\hline & \multicolumn{3}{c}{$\begin{array}{c}\text { Superior rubber } \\
\text { seed }\end{array}$} & \multicolumn{3}{c}{$\begin{array}{c}\text { Local rubber } \\
\text { seed }\end{array}$} \\
\cline { 2 - 7 } & BS & PS & LS & BL & PL & LL \\
\hline Weight of Flour & 38.6 & 41.3 & 50.3 & 59.0 & 59.0 & 53.0 \\
Moisture & 3.01 & 2.90 & 3.34 & 3.91 & 3.71 & 4.02 \\
content Ash & 2.89 & 2.77 & 3.11 & 4.32 & 4.02 & 4.43 \\
Content & 43.5 & 44.2 & 40.5 & 38.8 & 39.9 & 36.8 \\
Oil content & & & & & & \\
\hline
\end{tabular}

Moisture content and ash content are important parameter for establishing the relationship between rubber seed oil and its properties (Abdulkadir, et al. 2015). In this study, the moisture content and ash content of local rubber seed are greater than superior rubber seeds for all altitude. The characteristic of rubber seed from Prabumulih district showed the most excellent quality value of water content and ash content are small. Oil is expected to have a small moisture content to reduce hydrolysis reaction. From the table, we can see that the superior rubber seed types have better quality than local rubber seed.

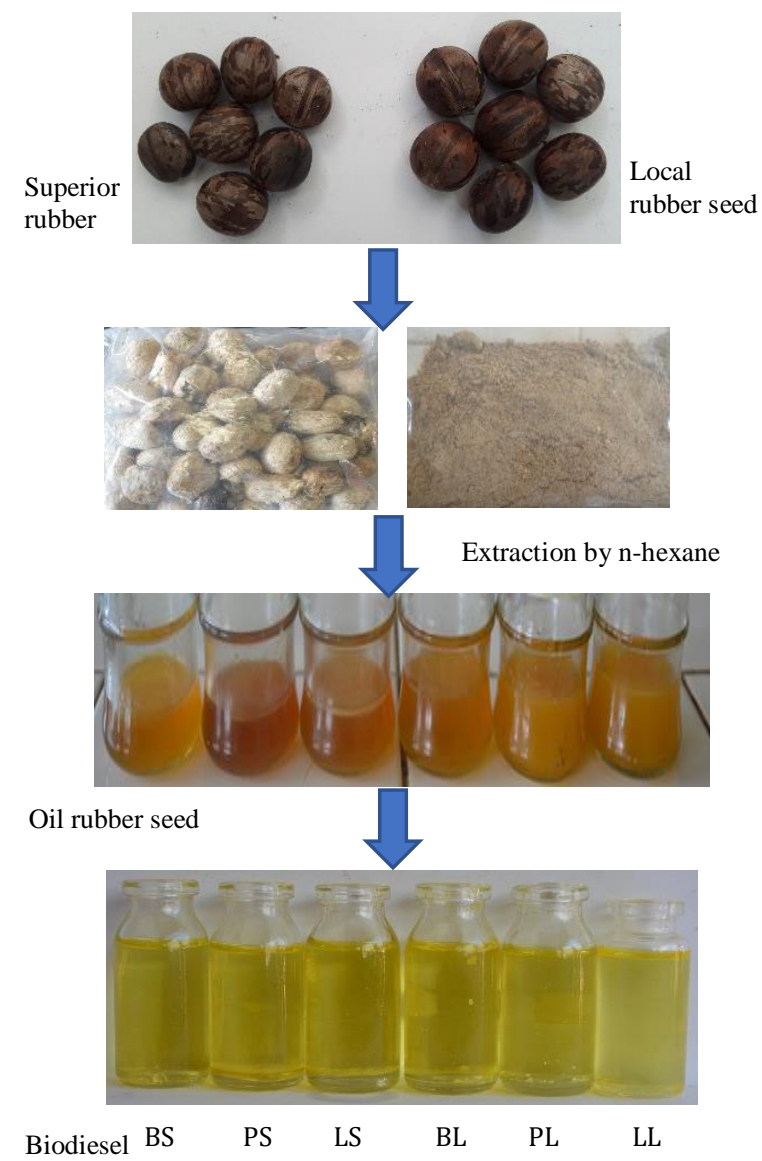

Fig. 2 Biodiesel from superior and local rubber seed oil from all altitude

Rubber seed oil is obtained by extraction using $n$ hexane solvent. The yield (\%) is parameters used to determine the amount of oil produced in the extraction 
Citation: Salni, S, Hariani, P.L. and Marisa, H. (2017) Influence the Rubber Seed Type and Altitude on Characteristic of Seed, Oil and Biodiesel.. Int. Journal of Renewable Energy Development, 6(2), 157-163, https://doi.org/10.14710/ijred.6.2.157-163

$\mathrm{P}$ a g e 160

process. The results showed that the percentage yield of superior rubber seed oil types is greater than the local rubber seeds for all altitude. The biggest amount of oil obtained from the superior rubber seed at Prabumulih district in $176 \mathrm{~m}$ above sea level of $44.2 \%$.

The area suitable for growing rubber is in the zone between $15^{\circ} \mathrm{LS}$ and $15^{\circ} \mathrm{LU}$. The rubber plant grows optimally in the lowlands between 0-200 meters above sea level and at a temperature $25-35^{\circ} \mathrm{C}$. An altitude more than $600 \mathrm{~m}$ above sea level is less suitable for rubber plant growth (Setyamidjaja, 1993). In this study, the oil content for Lahat district have the less oil content. The altitude more than $600 \mathrm{~m}$ above sea level. The tropics have a similar climate, but the difference in altitude causes differences in temperature, humidity and rainfall. The higher of elevation impacts the lower temperature and the higher the humidity. This it inhibit the growth of rubber plants (Andrian, et al. 2014).

\subsection{Characteristic of Rubber Seed Oil}

Figure 2 shows the superior and local rubber seed oil and biodiesel produced. The volume of superior rubber seed is smaller than the local rubber seed. The physical and chemical characteristic of rubber seed oil are shown in Table 2. The parameters analyzed on rubber seed oil include free fatty acids, viscosity, and fatty acid composition. From the result, the FFA of superior rubber seed oil is 13.897-15.494\% while local rubber seed oil has less FFA of 9.786-10.399 \%. Both rubber seed oil has high content of FFA, therefore it is required to perform esterification to reduce FFA. The high content of FFA also produced from rubber seed oil obtained by mechanical press, which is 10.39-16.48 \% (Widayat \& Suherman, 2012).

Table 2

Characteristics of Rubber Seeds Oil

\begin{tabular}{lcccccc}
\multicolumn{1}{c}{ Parameter } & \multicolumn{3}{c}{ Superior rubber seed } & \multicolumn{2}{c}{ Local rubber seed } \\
\cline { 2 - 7 } & BS & PS & LS & BL & PL & LL \\
\hline Free fatty acid (\%) & 15.494 & 14.207 & 13.897 & 10.094 & 10.399 & 9.786 \\
Viscosity (Cst) & 41.873 & 41.790 & 41.458 & 35.526 & 35.066 & 34.115 \\
Fatty acid (\%) & & & & & & \\
- Pentadecanoic acid & 12.01 & 12.56 & 5.00 & 12.15 & 11.74 & 5.18 \\
- Linoleic acid & 57.42 & 55.15 & 31.72 & 57.44 & 57.86 & 25.55 \\
- Octadecanoid acid & 19.26 & 22.37 & 7.28 & 19.12 & 20.59 & 54.26 \\
- Stearic acid & 9.11 & 8.93 & 28.38 & 9.85 & 8.55 & - \\
- Palmitic acid & - & 0.59 & 18.93 & - & - & - \\
- Pentanoic acid & - & - & - & - & - & 12.48 \\
- others & 2.20 & 0.40 & 8.69 & 1.44 & 1.26 & 2.53 \\
\hline
\end{tabular}

Viscosity is an intrinsic fluid property that shows resistance to the flow of fluid. The viscosity of superior rubber seed oil from different altitude with the value of 41.873, 41.790 and 41.458 Cst are greater than from local rubber seed oil with the value of 35.526, 35,066 and $34.115 \mathrm{cSt}$. Another study shows that viscosity of rubber seed oil is 66.2 (Ramadhas, et al. 2005) and 34.69 cSt (Satyanarayana \& Muraleedharan, 2010), respectively.

The determination of fatty acid composition using GC-MS showed that rubber seed oil consists mainly of linoleic acid except local rubber seed oil from Lahat district (LL) with the large percentage of $54.26 \%$ octadecanoic acid. The difference of fatty acid content in the rubber seed oil can be caused by different types of rubber and altitude. The composition and percentage of fatty acids in seed oil of local and superior rubber seed on Banyuasin and Prabumulih district not significantly different. Both areas have almost the same altitude less than 200 above sea level.

The linoleic acid classified as unsaturated fatty acids with the atomic number 18 and two double bonds. The same result reported Pianthong \& Prachasanti
(2009); Yousif et al. (2013), Gimbun et al. (2013), Bello \& Otu (2015) and Awulu et al. (2015) that the main content of rubber seed oil is linoleic acid with percentage of $41.38,36.31,20.07,37.7$ and $37.5 \%$, respectively. The results showed that the fatty acids from local and superior rubber seeds in Lahat district with altitude more than $600 \mathrm{~m}$ have a different composition than others. The chromatogram of fatty acid from superior rubber seed and local rubber seed oil presented in figure 3 .

\subsection{Biodiesel from Superior Rubber Seed Oil and Local Rubber seed oil}

Synthesis of biodiesel performed with 2 steps, the first step is esterification using acid catalyst and the second step is transesterification using a based catalyst. The aims of esterification reaction are to reduce free fatty acids and water content. The presence of water in the biodiesel cause corrosion in the combustion chamber when used as fuel. In addition, high FFA cause low production of biodiesel (Zamberri \& Ani, 2016). 

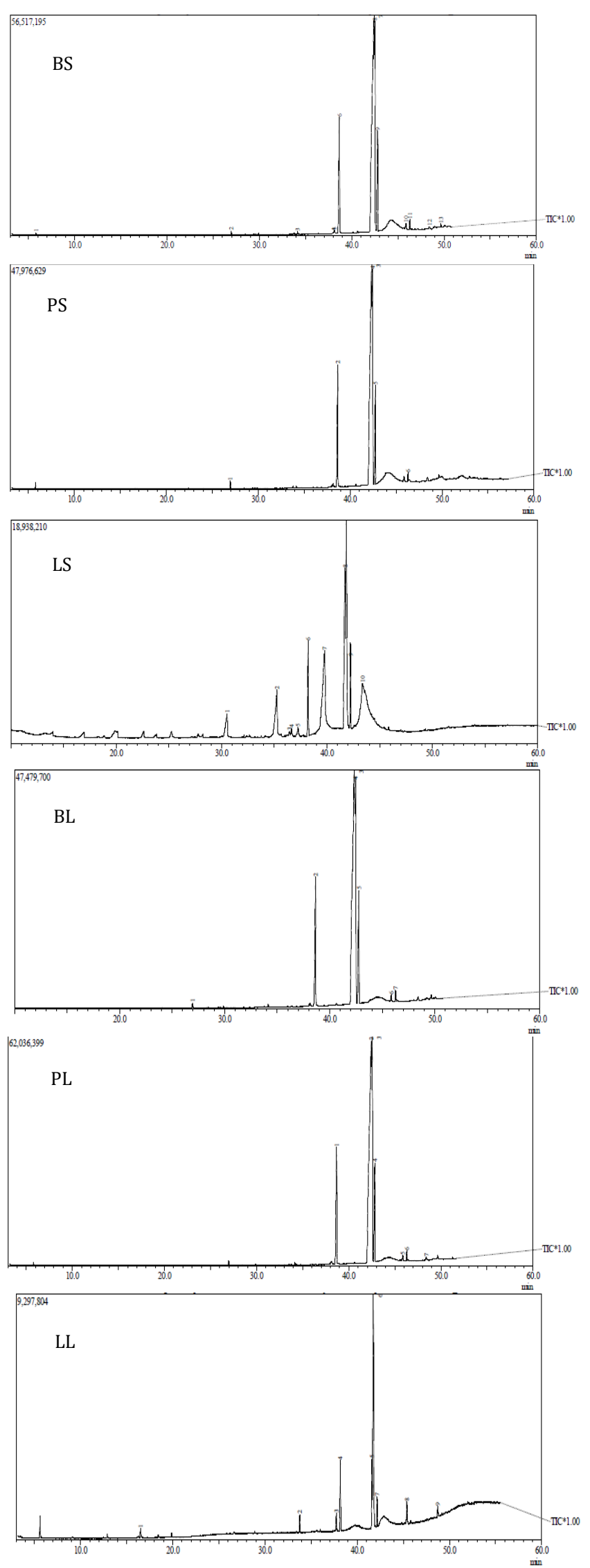

Fig. 3 GC-Chromatogram of fatty acid from rubber seed oil
The esterification process is carried out using $\mathrm{H}_{2} \mathrm{SO}_{4}$ as catalyst in a closed condition resulting in a very significant reduction of FFA. The high FFA content contributed to higher saponification and low yield biodiesel. In this study, the content of free fatty acids of superior rubber seed oil is reduced from 13.897$15.494 \mathrm{mg} / \mathrm{g}$ to $1.104-2.017 \mathrm{mg} / \mathrm{g}$ while local rubber seed oil is reduced from $9.786-10.399$ to $0.598-0.630 \mathrm{mg} / \mathrm{g}$. Figure 4 shows the FFA of rubber seed oil for all type and altitude. The larger volume of oil, the greater value of FFA. The FFA value in superior rubber seed oil is bigger than local rubber seed but altitude does not affect to FFA value. There are significant different for all FFA value in rubber seed oil before and after esterification.

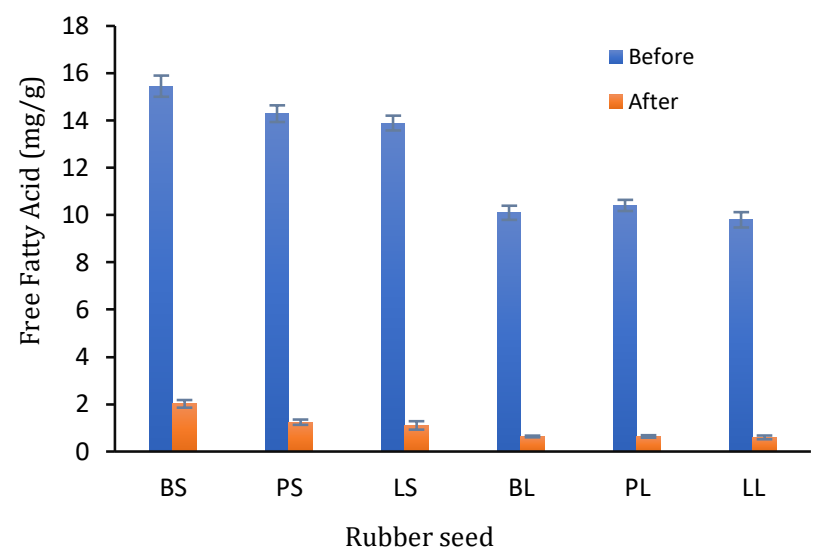

Fig. 4 The FFA of rubber seed oil before and after esterification

Table 3 shows the characteristic of biodiesel from local and superior rubber seed oil from all altitude by transesterification using methanol and $\mathrm{NaOH}$ as catalyst. Analysis of methyl ester product includes cetane index, flash point, kinematic viscosity, carno residue, moisture content, water and sediment content and destilation.

The value of cetane index depends on distributed and long fatty acid (Laza \& Bereczky, 2010). The methyl ester of superior rubber seed from Prabumulih and Banyuasin District have the highest value cetane index and qualified to minimum standard of biodiesel according to the SNI. The both of methyl ester has a similarity that is dominated by unsaturated fatty acids is linoleic acid.

Flash point is the lowest temperature of biodiesel where oil vapor and air mixture to be burned. The standard value of the minimum flash point (SNI 7182) is $100^{\circ} \mathrm{C}$. In this study, the highest flash point is the biodiesel for superior rubber seed from Banyuasin and Prabumulih district and all of the methyl ester according to the SNI. The other research shows methyl ester from rubber seed has a different flash point of 185, 194 and $237{ }^{\circ} \mathrm{C}$ (Ibrahim \& Pillai, 2011; Ramadhas, et al. 2005, Satyanarayana \& Muraleedharan, 2010). 
Citation: Salni, S, Hariani, P.L. and Marisa, H. (2017) Influence the Rubber Seed Type and Altitude on Characteristic of Seed, Oil and Biodiesel.. Int. Journal of Renewable Energy Development, 6(2), 157-163, https://doi.org/10.14710/ijred.6.2.157-163

$\mathrm{P}$ a g e 162

Table 3

Characteristics of Biodiesel

\begin{tabular}{|c|c|c|c|c|c|c|c|c|}
\hline \multirow[t]{2}{*}{ Parameter of biodiesel } & \multicolumn{3}{|c|}{ Superior rubber seed } & \multicolumn{3}{|c|}{ Local rubber seed } & \multirow[t]{2}{*}{ SNI 7182} & \multirow{2}{*}{$\begin{array}{c}\text { ASTM D6751- } \\
02\end{array}$} \\
\hline & BS & PS & LS & BL & PL & $\mathbf{L L}$ & & \\
\hline Cetane Index & 51.23 & 53.03 & 41.23 & 48.25 & 50.34 & 40.98 & 51 Min & 47 Min \\
\hline Flash point $\left({ }^{\circ} \mathrm{C}\right)$ & 179 & 180 & 168 & 162 & 161 & 156 & $100 \mathrm{Min}$ & - \\
\hline Kinematic Viscosity, $40^{\circ} \mathrm{C}(\mathrm{cSt})$ & 5.67 & 5.69 & 4.89 & 4.68 & 4.23 & 3.95 & $2.3-6.0$ & $1.9-6.0$ \\
\hline Carbon residue (\%) & 0.043 & 0.048 & 0.057 & 0.049 & 0.053 & 0.061 & $0.05 \mathrm{Max}$ & $0.05 \operatorname{Max}$ \\
\hline Density $\left(\mathrm{kg} / \mathrm{m}^{3}\right)$ & 878.9 & 877.2 & 875.6 & 853.1 & 8571.6 & 855.8 & $850-890$ & - \\
\hline Moisture content (mg/L) & 482 & 477 & 496 & 495 & 497 & 501 & $500 \mathrm{Max}$ & - \\
\hline Water and Sediment content (\%) & 0.026 & 0.027 & 0.029 & 0.025 & 0.026 & 0.026 & $0.05 \mathrm{Max}$ & - \\
\hline Distillation $\left({ }^{\circ} \mathrm{C}\right)$ & 345 & 351 & 375 & 341 & 352 & 382 & 360 Max & $360 \mathrm{Max}$ \\
\hline
\end{tabular}

The viscosity is an important test in the biodiesel. The operation of fuel injection equipment influenced by viscosity (Bello \& Otu, 2015). The viscosity of biodiesel from all type and altitude is in the range of 3.95-5.89 cSt. The high viscosity of the biodiesel was obtained from superior rubber seed from Banyuasin and Prabumulih district. This is correlated with the number of carbon atoms and the double bonds carbon of the fatty acids. The more number of carbon atoms and the double bonds carbon will result in greater viscosity.

The sediment should be avoided to prevent build up that causes damage to the diesel engine. In this study, carbon residue of superior and local rubber seed from Lahat District are above the standard carbon residue of biodiesel of maximum $0.05 \%$ (SNI 7182; ASTM D6751-02).

Some research reported that rubber seed oil has high density, after transesterification process to be reduced (Bello \& Otu, 2015). The standard of density in the range $850-890 \mathrm{~kg} / \mathrm{m}^{3}$. The result shows that density of biodiesel from superior rubber seed is greater than local rubber seed for all altitude and all of methyl ester according to SNI.

The moisture content can cause imperfect combustion, furthermore water is in contact with the sulfur oxide will cause corrosion of the metals in the combustion chamber. The maximum value of the biodiesel according to ASTM D6751-02 is $500 \mathrm{mg} / \mathrm{L}$. In this study only methyl ester from local rubber seed in Lahat district that does not qualify. The main component of rubber seed oil of decanoid acid which is different with the other rubber seed oils.

In this study, sediment analysis shows that biodiesel in all types and altitude are qualified the requirements which is less than $0.05 \%$. The aim of sediment analysis to investigate the presence of particles, such as sand, dirt, or compounds that dissolve and including suspension and metal. Sediment is corrosive, which would cause air pollution and lower the cetane number of a fuel oil. Sediment can also poison the catalyst.

The ease of a liquid turns to gas plays an important role in mixture of air and diesel fuel at the time of ignition in diesel engine combustion chamber. The distillation of biodiesel of superior and local rubber seed in Lahat which are not qualified the maximum distillation of $360^{\circ} \mathrm{C}$.

\section{Conclusion}

The rubber plants can be planted by selected clones (superior rubber seed) and seeds seedlings (local rubber seed). The type of rubber seeds of the rubber trees planted in South Sumatra affect the quality of rubber seed, oil, and methyl ester. The altitude does not have a positive effect on the quality of rubber seed, oil, and methyl ester. The methyl ester product from superior rubber seed at Banyuasin District (18 m above sea level) and Prabumulih District (176 m above sea level) have similar quality and according to the standard of biodiesel (SNI 7182 and ASTM D6751-02).

\section{Acknowledgments}

We are grateful to Sriwijaya University for funding research No. 592/UN9.3.1/LT/2016, Department of Biology and Department of Chemistry, Faculty of Mathematics and Natural Science for facilities research.

\section{References}

Abdulkadir, B.A., Yoshimitsu, U., Anita, R., Noridah, Bt, O., Katsuki, K., \& Takami, K. (2015)Production of Biodiesel from Rubber Seeds (Hevea Brasiliensis) by In Situ Transesterification Method. Journal of the Japan Institute of Energy, 94,763-768

Andrian, Supriadi., \& Purba, M. (2014) The Effect of Elevation and Slope on Rubber (Hevea brasiliensis Muell. Arg.) Production in PTPN III Hapesong Farm of South Tapanuli. Jurnal Online Agroteknologi, 2(3), 981:989

Ahmad, J., Suzana, Y., Awais, B., \& Ruzaimah, N.M.K. (2014) Biodiesel production from the High Free Fatty Acid "Hevea Brasiliensis" and Fuel Properties Characterization. Applied Mechanics and Materials, 625, 897-900

Awulu1, J.O., Ogbehb, G.O., \& Asawac. (2015) Comparative Analysis of Biodiesels from Calabash and Rubber Seeds Oils. 
International Journal of Renewable Energy Development, 4(2), 131-136

Bello, E.I., \& Otu, F. (2015) Physicochemical Properties of Rubber (Hevea Brasiliensis) Seed Oil, Its Biodiesel, and Blends with Diesel. British Journal of Applied Science and Technology, 6(3), 261-275

Chuah, L.F., Suzana, Y., Abdul, R.A.A., Jiri, J.K., Awais, B., \& Mohd, Z.A. (2015) Influence of Fatty Acids Content in NonEdible Oil for Biodiesel Properties. Clean Techn Environ Policy, 1-10

Dizajeyekan, Y.I., Ahmad, R.H., \& Tohid, E.G. (2016) Regional Altitude and Soil Physicochemical Factors Influence the Essential Oil of Thymus pubescens (Lamiales: Lamiaceae). J. Biol. Environ. Sci., 10(29), 45-51

Gimbun, J., Shahid, A., Chitra, C.S.C.K., Liyana, A.S., Nurul, H.M.G., Chin, K.C., \& Said, N. (2012) Biodiesel Production from Rubber Seed Oil Using A Limestone Based Catalyst. Advances in Materials Physics and Chemistry, 2, 138-141

Hossain, A.B.M.S., \& Mazen, M.A. (2010) Effects of Catalyst Types and Concentrations on Biodiesel Production from Waste Soybean Oil Biomass as Renewable Energy and Environmental Recycling Process. Australian Journal of Crop Science, 4(7), 550-555

Ibrahim, A.M., \& Pillai, B.C. (2011) Optimization of Process Parameters for Biodiesel Extraction from Rubber Seed Oil Using Central Composite Design. International Journal of Production Technology and Management Research, 2(1), 2229-3140

Ikwuagwu, O.E., Ononogbu, I.C., \& Njoku, O.U. (2000) Production of Biodiesel Using Rubber [(Hevea Brasiliensis(Kunth. Muell)] Seed Oil. Industrial Crops and Products, 12, 57-62

Ketaren, S. (1986) Pengantar Teknologi Minyak dan Lemak Pangan, UI Press, Jakarta

Khazaai, S.N.M., Gaanty, P.M., Mohd, H.A.R., Mashitah, M.Y., \& Yukihiko, M. (2017) Review on Methyl Ester Production from Indible Rubber Seed Oil under Various Catalyst. Industrial Crops and Products, 97, 191-195

Kittigowittana, k., Wongsakul, S., Krisdaphong, P., jimtaisong, A., \& Saewan, N. (2013) Fatty Acid Composition and Biological Activities of Seed Oil from Rubber (Hevea Brasiliensis) Cultivar RRIM 600. International Journal of Applied Research in Natural Products, 6(2), 1-7

Kouzu, M., Kasuno, T., Tajika, M., Yamanaka, S. \& Hidaka, J. (2008) Active Phase of Calcium Oxide used as Solid Base Catalyst for Transesterification of Soybean Oil with Refluxing Methanol. Applied Catalysis, 334(1-2), 357-365
Laza, T., \& Bereczky, C. (2010) Basic Fuel Properties of Rapeseed Oil-Higher Alcohol Blends. Fuel, 20(2), 803-810

Marchetti, J.M., and Errazu, A.F. (2008) Esterification of Free Fatty Acids using Sulfuric Acid as Catalyst in the Presence of Triglycerides. Biomass and Bioenergy, 32(9), 892-895

Pianthong, K., \& Prachasanti, T. (2009) Production of Biodiesel Seed Oil and Its Effects to Engine Performances. International Conference on Energy Security and Climate Change: Problems \& Issues in GMS.

Ramadhas, A.S., Jayaraj, S., \& Muraleedharan, C. (2005) Biodiesel Production from High FFA Rubber Seed Oil. Fuel, $84,335-340$

Satyanarayana, M., \& Muraleedharan, C. (2010) Methyl ester Production from Rubberseed Oil using Two-Step Pretreatment Process. International Journal Of Green Energy, 7(1), 84-90.

Shams, M., Mahdi, R., Sasan, Z.E., Ehsan, Z.E., Atilla, D., \& Ertan, Y. (2016) Effects of Climatic Factors on the Quantity of Essential Oil and Dry Matter Yield of Coriander (Coriandrum sativum L.). Indian Journal of Science and Technology, 9(6), 1-4

Setyamidjaja, D. (1993) Karet: Budidaya dan Pengolahan. Kanisius. Yogyakarta

Rouas, S., Mohammed, R., Abdrraouf, E.A., Lahoussaine, B., Drissia, J.I., Abdelaziz, S., \& Nadia, M. (2016) Effect of Geographical Conditions (Altitude and pedology) and Age of Olive Plantations on the Typicality of Olive Oil In Moulay Driss Zarhoun. Mediterranean Journal of Biosciences, 1(3), 128-137

Widayat, Agam, D.K.W., \& Hadiyanto. (2013) Study on Production Process of Biodiesel from Rubber Seed (Hevea Brasiliensis)by In Situ (Trans)esterification Method with Acid Catalyst. International Conference on Sustainable Energy Engineering and Application, Energy Procedia, 32, 64-73

Widayat., W \& Suherman, S. (2012) Biodiesel production from Rubber seed Oil via Esterification Process. International Journal of Renewable Energy Development, 192), 57-60

Yousif, E., Bashar, A., Hanan, I., Jumat, S., \& Nadia, S. (2013) Rubber Seed Oil Properties, Authentication and Quality Assesment Using (Chloroform: Methanol) as Solvent. Journal of Al-Nahrain University, 16(3), 1-6

Zamberi, M.M., \& Ani, F.N. (2016) Biodiesel Production from High FFA Rubber Seed Oil Using Waste Cockles. ARPN Journal of Engineering and Applied Sciences, 11(12), 77827787 